\title{
EFFECTIVENESS OF YOGA PRANA VIDYA PRACTICE PROTOCOLS FOR HEALTH IMPROVEMENTS AND BOOSTING IMMUNITY OF SENIORS - A REVIEW
}

\author{
Venkata Satyanarayana Nanduri* \\ Research \& Publications, Yoga Prana Vidya Ashram, Sri Ramana Trust, Thally-6351 18, India
}

(Received on Date: $1^{\text {st }}$ June 2020 Date of Acceptance: $6^{\text {th }}$ June 2020 Date of Publish: $01^{\text {st }}$ July 2020)

Email: vsnanduri@yahoo.com

\begin{abstract}
Introduction: Life for senior citizens, in all cultures globally, is very challenging - physically, mentally and emotionally, leading to a gradual decline in physical and mental capacity with a risk of disease ingress, and an earlier death. Yoga Prana Vidya (YPV) is one integrated system that offers a set of easily practicable protocols to help older population maintain physical and mental health holistically. In the context of COVID 19, available data reveals that most of the patients deceased are seniors and 85 to $90 \%$ deceased had comorbid conditions such as diabetes and hypertension. Methods: Review method is used to identify, collect and synthesize available evidence in respect of the effective applications of YPV for seniors and how it can help them aging successfully. Eight published articles are reviewed on the effectiveness of YPV for various diseases and health conditions of seniors. Findings: This review confirms positive effects of practicing YPV with controlled diet by older people, such as cognitive abilities, emotional stability, weight reduction and control of BMI, less relapse and less new disease proneness, body flexibility, mobility, and boosted immunity to counter infections. Regular practice of YPV protocols enables balancing left and right brains achieving balance between emotion and cognition. Conclusion: YPV as an integrated, holistic and safe system is appropriate approach for older people to stay healthy and fit, and additionally it develops spiritual dimension also through meditations.
\end{abstract}

Keywords: Yoga Prana Vidya, YPV, older population, healthy aging, integrated system, holistic 


\section{INTRODUCTION}

People worldwide are living longer (WHO, 2018). Presently, for the first time in history, most people can expect to live into their sixties and beyond. By 2050, the world's population aged 60 years and older is expected to total 2 billion, up from 900 million in 2015. Today, 125 million people are aged 80 years or older. According to WHO (2018), by $2050,80 \%$ of all older people will live in low- and middle-income countries.

Life for seniors, such as those for example aged 65 years and above, is generally very challenging, physically and mentally, in all cultures. Ageing of human body at the biological level results from accumulated damage at molecular and cellular level impacting in course of time. This leads to a gradual decline in physical and mental capacity with a risk of disease ingress, and ultimately, death. These changes are normally associated with a person's age in years through sixties and above. While some seventy year-olds enjoy extremely good health and functioning, most other seventy year-olds are relatively weaker and require significant help from others. Yoga Prana Vidya (YPV) is one integrated

system that offers a set of easily practicable protocols to help this kind of older population to maintain physical and mental health holistically.

Considering additional risks such as in the context of COVID 19, the data collected from hospitals in Indore, India on the patients indicated that most of those died are seniors and 85 to $90 \%$ deceased had comorbid conditions such as diabetes and hypertension (Roy/Free Press Indore, 2020). Experience shows that regular practice of Yoga Prana Vidya (YPV) protocols, which is non-drug and non-touch process, cures diseases and boosts immunity. Therefore, the purpose of this review is to collect and synthesize available evidence in respect of the effective applications of Yoga Prana Vidya for seniors and how it can help them aging successfully minimising risk factors practically.

\section{Materials and Methods}

This paper uses a review method. A search of published articles on applications of YPV to various cases and samples is made, and a total of 8 articles as shown in table 1 are reviewed to assess the effectiveness of YPV particularly in cases of older people. 
Table 1: Published Yoga Prana Vidya (YPV) articles analysed in this review

\begin{tabular}{|c|c|c|c|c|}
\hline S.No. & Title & Authors & $\begin{array}{l}\text { Sample who } \\
\text { practiced YPV } \\
\text { and got healed }\end{array}$ & $\begin{array}{l}\text { Outcomes for the } \\
\text { sample }\end{array}$ \\
\hline [1] & $\begin{array}{l}\text { A study of the effects of Yoga Prana Vidya one } \\
\text { month intensive residential programme for } \\
\text { participants on their physical health, } \\
\text { psychological well-being and improved } \\
\text { immunity }\end{array}$ & $\begin{array}{l}\text { Reddy NJ \& } \\
\text { Nanduri VS } \\
\text { (2020) }\end{array}$ & $\begin{array}{l}12 \text { female } \\
\text { participants } \\
\text { with average } \\
\text { age } 44.15\end{array}$ & $\begin{array}{l}\text { 1. weight } \\
\text { reduction } \\
\text { 2. Right BMI } \\
\text { 3. Brain wave } \\
\text { balance } \\
\text { 4. improved } \\
\text { Spirometry results } \\
\text { 5. Emotional } \\
\text { balance } \\
\text { 6. Cognitive } \\
\text { abilities }\end{array}$ \\
\hline [2] & $\begin{array}{l}\text { Successful healing treatment of high blood } \\
\text { cholesterol levels and asthma using Yoga } \\
\text { Prana Vidya (YPV) system: A case study of } \\
\text { self-healing. }\end{array}$ & $\begin{array}{l}\text { Nanduri,VS } \\
\& \\
\text { Vasavada, A } \\
\text { (2019) }\end{array}$ & $\begin{array}{l}\text { One male aged } \\
\text { 33, Symptoms: } \\
\text { Asthma \& High } \\
\text { cholesterol }\end{array}$ & $\begin{array}{l}\text { Self-healing and } \\
\text { YPV practice } \\
\text { cured the diseases } \\
\text { within } 6 \text { months }\end{array}$ \\
\hline [3] & $\begin{array}{l}\text { How the participants of a Yoga Prana Vidya } \\
\text { YPV) eye camp experienced vision } \\
\text { improvements: A case study }\end{array}$ & $\begin{array}{l}\text { Nanduri, VS } \\
\text { \& Chaitra, N } \\
\text { (2019) }\end{array}$ & $\begin{array}{l}3 \text { Patients aged } \\
42,43 \text { and } 64 \\
\text { out of } 27 \\
\text { participants. }\end{array}$ & $\begin{array}{l}\text { Blurred vision } \\
\text { improved. }\end{array}$ \\
\hline [4] & $\begin{array}{l}\text { A case report of the Exostosis of ear of an } \\
\text { elderly female: Successful healing with } \\
\text { Integrated Yoga Prana Vidya(YPV)healing } \\
\text { approach as alternative to surgical intervention }\end{array}$ & $\begin{array}{l}\text { Gupta, K \& } \\
\text { Nanduri, VS } \\
\text { (2019) }\end{array}$ & $\begin{array}{l}\text { A } 64 \text { year old } \\
\text { female patient } \\
\text { suffering from } \\
\text { Exostosis of the } \\
\text { ear }\end{array}$ & $\begin{array}{l}\text { She was healed } \\
\text { and cured without } \\
\text { surgery }\end{array}$ \\
\hline [5] & $\begin{array}{l}\text { Management of Post-Herpetic Neuralgia } \\
\text { (PHN) by Yoga Prana Vidya Healing (YPV): } \\
\text { A case study }\end{array}$ & $\begin{array}{l}\text { Sachdeva R } \\
\& \text { Nanduri, } \\
\text { VS } \\
(2019)\end{array}$ & $\begin{array}{l}\text { A } 45 \text { year old } \\
\text { male patient } \\
\text { suffering from } \\
\text { Post herpetic } \\
\text { neuralgia }\end{array}$ & $\begin{array}{l}\text { Within a week the } \\
\text { patient was } \\
\text { completely } \\
\text { relieved of the } \\
\text { pain. }\end{array}$ \\
\hline [6] & $\begin{array}{l}\text { Cardiac Case Study: Successful Healing } \\
\text { Treatment of A 48-Year-Old Male with } \\
\text { Arterial block in Heart, Using Yoga Prana } \\
\text { Vidya (YPV) Healing System }\end{array}$ & $\begin{array}{l}\text { Ramya A \& } \\
\text { Nanduri VS } \\
\text { (2019) }\end{array}$ & $\begin{array}{l}\text { A } 48 \text { year old } \\
\text { male patient } \\
\text { diagnosed with } \\
\text { arterial block in } \\
\text { heart }\end{array}$ & $\begin{array}{l}\text { Medical } \\
\text { investigation after } \\
\text { YPV healing } \\
\text { confirmed that the } \\
\text { arterial blocks } \\
\text { disappeared after } \\
\text { healing sessions. }\end{array}$ \\
\hline [7] & $\begin{array}{l}\text { Diabetes Management and Control Using } \\
\text { Yoga Prana Vidya (YPV) Healing System }\end{array}$ & $\begin{array}{l}\text { Ashalatha } \\
\text { HR, Ramya } \\
\text { A \& } \\
\text { Nanduri VS } \\
(2019)\end{array}$ & $\begin{array}{l}\text { Sample of } 19 \\
\text { patients , mean } \\
\text { age } 59 \text { years, } \\
\text { known diabetics }\end{array}$ & $\begin{array}{l}\text { YPV healing and } \\
\text { protocols } \\
\text { practiced for } 2 \text { to } \\
3 \text { months } \\
\text { improved patient } \\
\text { condition by } 80 \%\end{array}$ \\
\hline [8] & $\begin{array}{l}\text { A study into successful treatment of some } \\
\text { difficult Medical cases using Yoga Prana } \\
\text { Vidya (YPV) Healing System as alternative } \\
\text { medicine }\end{array}$ & $\begin{array}{l}\text { Neravetla, J } \\
\& \text { Nanduri } \\
\text { VS (2019) }\end{array}$ & $\begin{array}{l}\text { Sample cases of } \\
\text { male 54, Male } \\
67, \text { Female } 49 \\
\text { and male } 23 \\
\text { year old, } \\
\text { having difficult } \\
\text { medical } \\
\text { conditions }\end{array}$ & $\begin{array}{l}\text { All were treated } \\
\text { fully and they are } \\
\text { now living normal } \\
\text { life. }\end{array}$ \\
\hline
\end{tabular}




\section{Results \& Discussion}

The analysis shows that majority of the cases reported successfully cured by use of YPV protocols and healing are older patients (above middle age). The patients had several diseases such as, diabetes type 2, hypertension (high BP), organ problems, arterial heart block, PHN(Postherpetic neuralgia), Exostosis of the ear, Eye (vision) problems, high cholesterol, Asthma, obesity and over-weight (high BMI), emotional disturbances and cognitive incapacities (mild).

The integrated YPV treatment protocols comprise of some self-practice items, specified fruit and veg diet at least one time daily, and some healing sessions by a practitioner. YPV self-practice protocols used by the patients consist of physical exercises including super brain asana, rhythmic breathing exercises, forgiveness sadhana, PPM (Planetary peace meditation). The special vegetarian diet consists of salt-less food, with plenty of fruit and vegetables, at least once daily. Additionally, qualified YPV healers give healings to the energy body and affected parts of the patients over a number of sessions, each session taking approximately 15 to 20 minutes, spread over several days and weeks depending on the severity and type of each case. The patient health conditions are holistically healed, i.e. physically, mentally and emotionally which a very balanced for social health too.

In all cases, medical reports before and after YPV treatment interventions are obtained to ensure satisfactory improvements and treatments. In addition, patient feedback in writing, either from the patient directly, or from a close relative accompanying the patient, is obtained for records. Further instructions to be followed after return to home are also given for follow up of the patient to check how the patient is sustaining the changes in life style.

Yoga generally implies to various body postures and most of these postures are not convenient to older people to learn and practice comfortably. In contrast, Yoga Prana Vidya is a proven integrated system of simple physical exercises, rhythmic breathing exercises and meditation techniques of Forgiveness and planetary peace. As stated in the YPV Sadhana App (2020), the physical exercises are simple to learn and practice and help people to gain mobility and flexibility without causing strain. The older people can gain more balance of physical body without risk of fall. Rhythmic breathing exercises enable increasing lung capacity and the blood gets detoxicated and oxygenated. This Rhythmic breathing process normalizes the energy centre connected with emotions thus reducing stress and its adverse effects. It is widely known that Forgiveness is therapeutic, and forgiving one-self and others is important for good health. Lastly, Planetary Peace meditation is very powerful and potent meditation that enables personal transformation and harmonious relations all around. YPV is thus observed to be an integrated system that works holistically for 
people of all age groups, and more so for older people regardless of their gender. When practiced in group this system is more effective than practiced alone.

\section{CONCLUSION}

The results obtained from this review confirm the positive effects of practicing YPV by older people in particular, with respect to maintaining cognitive abilities, less relapse and less new disease proneness, body flexibility, and mobility. It is also evident that regular practice of YPV protocols enables balancing left and right brains achieving cognition-emotion balance. Weight reduction and BMI maintenance at normal levels, together with controlled diet, contributes to mobility and overall health. Finally, the comfortable and ideal approach for older people to stay healthy and fit is to regularly practice integrated system like YPV that additionally develops spiritual dimension also through the forgiveness and planetary peace meditations. They will consequently experience boosted immunity to counter bacterial and viral attacks.

\section{ACKNOWLEDGEMENTS}

Grateful acknowledgements are to the authors of the sourced articles for this review. And to Sri Ramana Trust for making available their documents and use of Copyright terms Yoga Prana Vidya TM and YPV $\odot$.

\section{CONFLICT OF INTEREST}

The author confirms that this study was conducted with own resources and without external financial support, and consequently no conflicts of interest exist in the publication of this article.

\section{REFERENCES}

Gupta, K \&Nanduri, V.S. (2019). A case report of the Exostosis of ear of an elderly female: Successful healing with Integrated Yoga Prana Vidya (YPV) healing approach as alternative to surgical intervention. Ann Geriatrics Educ Med Sci 2019 6(2): 42-47.

Nanduri, V.S \& Chaitra, N. (2019). How the participants of a Yoga Prana Vidya (YPV) Eye Camp experienced vision improvements: A Case study. The Journal of Community Health Management. (2019) 6(4):

Nanduri, V.S \&Vasavda, A. (2019). Successful healing treatment of high blood cholesterol levels and asthma using Yoga Prana Vidya (YPV) system: A case study of self-healing. Panacea Journal of Medical Sciences, September - December, 2019; 9 (3): $131-137$

Neravetla, J \& Nanduri, V.S. (2019). A study into successful treatment of some difficult Medical cases using Yoga Prana Vidya (YPV) Healing System as alternative medicine. International Journal of Scientific \& Engineering Research Volume 10, Issue 7 , July-2019

Neravetla, J \& Nanduri, V S. (2020). A study of the effects of Yoga Prana Vidya one 
month intensive residential programme for participants on their physical health, psychological well-being and improved immunity. International Journal of Research and Analytical Reviews (IJRAR), $7(2), 18-27$.

\section{Rajagopal, A.H., Ashwin, R \& Nanduri, V.S.} (2019).Diabetes Management and Control Using Yoga Prana Vidya (YPV) Healing System. Journal of Biology and Life Science ISSN 2157-6076 2019, Vol. 10, No. 2

Sachdeva, R \& Nanduri, V.S. (2019). Management of Post-herpetic Neuralgia (PHN) by Yoga Prana Vidya (YPV) healing: A case study. American J of Bio-medical and Life sciences, Vol.7 No.6, 2019, pp.174178

Ramya A, \& Nanduri, V.S. (2019). Cardiac Case Study: Successful Healing Treatment of a 48-Year-Old Male with Block in Heart, Using Yoga Prana Vidya (YPV) Healing System. Saudi J Nurs Health Care, Nov 2019; 2(11): 353-356.

Roy, R/Free Press Indore, (May 29, 2020). Information from Indore Hospitals of COVID 19 cases. Personal communication received by YPV Research team.

WHO. (2018). Ageing and Health. Retrieved from https://www.who.int/newsroom/fact-sheets/detail/ageing-andhealth

YPV Sadhana App (English). (2020). Available Google Play store for free access 